\title{
OCORRÊNCIA DE Varroa jacobsoni OUDEMANS PARASITANDO mellifera L., NO ESTADO DE RORAIMA
}

Sílvio José Reis da Silva Mirtes $\mathrm{MelO} \mathrm{O}^{2}$

Em março de 1991, durante inspeção de rotina no apiário da EMBRAPA, Centro de Pesquisa Agroflorestal de Roraima, localizado no campo experimental Bom Intento, a $27 \mathrm{Km}$ de Boa Vista, encontrou-se ácaros parasitando larvas e adultos de Apis mellifera.

Exemplares parasitados foram coletados e levados para laboratório afim de separar amostras dos parasitas, depois de observados foram conservados em álcool a 70\%, sendo que parte das amostras foram enviadas ao Centro Nacional de Defesa da Agricultura da EMBRAPA, onde foram identificados como sendo Varroa jacobsoni.

Em vários países, devido ao parasitismo dos estádios jovens e adulto, este ácaro tem se constituído um problema para a apicultura. Os danos variam desde a diminuição no peso das larvas e longevidade dos adultos até mesmo a extinção total das colônias (MORSE, 1986).

A introdução deste ácaro no Brasil data de 1971 através da importação de rainhas e enxames oriundos do Paraguai (MESSAGE, 1983). No Brasil não se tem dados sobre o extermínio ou mesmo efeitos drásticos sobre as colônias de Apis mellifera, ocasionados por este ácaro.

Em Roraima, embora tenha sido encontrado uma baixa porcentagem de abelhas infestadas por colmeia $(0,88 \%$ a $12,12 \%)$ em apiário situado na aldeia do Contão (SILVA, não publicado), é necessário ficar atento a uma possível evolução do problema, através de observações frequentes nas diversas localidades.

\footnotetext{
1 Museu Integrado de Roraima, Parque Anauá, Av. Brigadeiro Eduardo Gomes, $\mathrm{s} / \mathrm{n}$ Boa Vista - RR.

2 EMBRAPA - Centro de Pesquisas da Agricultura de Clima temperado, C. P. 403, Pelotas - RS.
}

Bol. do Mus. Integrado de Roraima, Boa Vista, 4 (único): 51-52, 1998 


\section{Agradecimentos:}

Agradecemos ao Dr. Gilberto Morais pela identificação do material.

\section{Bibliografia:}

MESSAGE, D. 1983. Patologia Apícola. Informe Agropecuário. 9: 71-6. MORSE, R. A. 1986. The Complete Guide To Beekeeping. 3 ed. E. P. Dutton, New York. 223p.

Bol. do Mus. Integrado de Roraima, Boa Vista, 4 (único) : 51-52, 1998 